\title{
ARE COMMUNICATION STRATEGIES FREQUENTLY USED IN SPEAKING CLASS?
}

\author{
Agung Wicaksono \\ Nusantara PGRI Kediri University \\ Agung_cerveni@yahoo.co.uk
}

\begin{abstract}
Abstact
Communication strategy is the way to help the speakers when facing difficulties in communication using English as a second language. This case study, at the first year students of English Department, aims to know the most frequent students' strategies to communicate in speaking activity in speaking class. It is found that thirteen communication strategies were used by the students in speaking English class, but not all of the communication strategies were used in every conversation, but only certain communication strategy was used. It depends on the materials difficulties. Furhermore, the most frequent communication strategies is stalling or time gaining strategy. As they need some time to think and then continue talking after they find the right words they need to communicate. This findings is in line with the propossed theory stated that communication strategy is defined as a systematic technique employed by a speaker to express his or her meaning when facing certain difficulties in communication.
\end{abstract}

Keywords: Communication Strategies, Speaking, Speaking Class.

\section{Introduction}

Second Language Acquisition (SLA) is a major subject that study about learning language after first language (L1) or it is called Second language (L2). The field of second language acquisition is old and new at the same time. It is old in the sense that scholars for centuries have been fascinated by the questions posed by the nature of foreign language learning and language teaching. It is new in the sense that the field, as it is now represented. In the earlier part of the modern phase, most scholarly articles emphasized language teaching and only had a secondary interest in language learning. In other words, the encouragement for studying second language learning was taken from pedagogical concerns. English in Indonesia is taught as foreign language (FL) or in second language acquisition called second language (L2). However, FL and L2 rarely same, FL is not used as daily communication in some countries like in Indonesia. Different with FL, L2 applied as daily communication after first language (L1). English is not L2 because Indonesian language is the L2 and commonly the L1 of Indonesian people is region language likes, Javanese, Sundanese, Madurese, etc. Nowadays, how to communicate effectively in Foreign Language Learning becomes much more important than reading and writing. However, in the process of learning, learners of foreign language or second language, of course have many difficulties. Not only in 
elementary, junior and senior high school, but also in college. The problems are various likes English does not use in daily life, the limited students' vocabularies, and knowledge of grammar, rare or never use it in society. It is proved from many researches about error analysis in many countries. English has four skills that must be mastered; those are listening, speaking, reading and writing. All of those skills are tools to communicate. It is divided into two ways of communication, one is oral communication and the second is written communication. Speaking is one of the four basic language skills that common use to communicate in daily life. It has closely relation with listening both of them belong to oral communication. Reading and writing as written communication. Speaking has been become the most common learned and the priority. Ellis (1997: 269) said that "A large percentage of the world's language learners study English in order to develop proficiency in speaking". Moreover, Ellis (1997: 269) claimed, "The mastery of speaking skills in English is a priority for many second or foreign language learners." In this research, the researcher discussed about communication strategies. As stated by Selinker in Bialystok (2008: 285) "Communication strategy is a deliberate attempt to express meaning when faced with difficulty in the second language." Therefore, communication strategies aim to help the speakers while they face difficulties with their language in order to communicate.
This research is conducted during speaking class in order to observe the strategies used during the speaking class. The term of communication strategies is often limited to strategies resorted to when the second language learner has difficulty with communicating. So the communication strategies is used when things is go wrong. So it is important to learn communication strategies as these are strategies helps learners to overcome problems when they communicate in L2 so they can convey their intended meaning. In addition Selinker in Byalistok (1994: 285) explains that a communication strategy is a deliberate attempt to express meaning when faced with difficulty in the second language. Eventually, Dorny in Brown (2000:128) states the strategies often used may include message abandonment, topic avoidance, circumlocution, substitution, coining new words, code switching to the first language, and asking for clarification.Dorny in Brown (2000:128).

\section{Method}

In order to reach the aims of this research that is to describe and to know the frequent communication strategies used by the first year students of English Department UNP Kediri, the case study is applied as a method of this research. The steps of conducting this research are; first, observing the situation of the class, taking field note and questionnaire, then analyzing the data and classifying the 
communication strategies applied by the students and the last is counting the frequent of communication strategies used. To collect the data, the closed-ended questionnaire, consists of thirteen questions and nonparticipant observation, field note and documentation are used.

\section{Result}

In categorizing and classifying the communication strategies, the researcher focused on his research only in the communication strategies used by the students in their speaking class when they practiced conversation with their partner and the most used of the communication strategies. The analysis is employed through some steps, namely: identifying the communication strategies, then classifying the communication strategies based on thirteen types of the communication strategies, and the last steps was describing the communication strategies. It is counting, tabulating, and presenting in percentages form. In this research, the researcher used two instruments to get the data, questionnaire and observation. The questionnaire answers are divided into three categories. There were often, seldom, and never used. The researcher gave score from the students' answer, 2 point for often, 1 point for seldom, and 0 point for never used. After that, the researcher tabulated and counted to get the result. Then the researcher observed in two meeting of speaking class. In the class the researcher watched and paid attention to the students' activities while wrote field note and took video recording to avoid missing moment in the class, like: their expression, their body language.

From the result of observation the researcher tabulated and counted by using formula below:

\section{The frequency of communication strategies

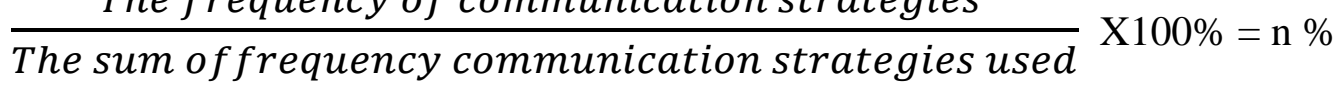

After finding the communication strategies in the field as above, the researcher counted and tabulated to get the clear result.

From the data analysis, the researcher found 13 communication strategies used by the students in speaking English class. But not in every conversation they used all, but only in certain situation the students used it. In this research the researcher found that the certain communication strategies often used. It was message abandonment, topic avoidance, circumlocution, approximation, literal translation, code switching, use of nonlinguistics means, appeal for help, stalling or time gaining strategy, and foreignizing. The complete results are can be seen in the following table: 
Table 1.

The Score of Questionnaire Answer

\begin{tabular}{|c|l|c|c|c|c|c|c|}
\hline No & $\begin{array}{l}\text { Communication } \\
\text { Strategies }\end{array}$ & Often & Score & Seldom & Score & Never & Point \\
\hline 1 & $\begin{array}{l}\text { Message } \\
\text { Abandonment }\end{array}$ & 9 & 18 & 20 & 20 & 12 & 0 \\
\hline 2 & Topic Avoidance & 8 & 16 & 21 & 21 & 12 & 0 \\
\hline 3 & Circumlocution & 23 & 46 & 14 & 14 & 4 & 0 \\
\hline 4 & Approximation & 27 & 54 & 8 & 8 & 6 & 0 \\
\hline 5 & $\begin{array}{l}\text { Use of All-Purpose } \\
\text { Words }\end{array}$ & 14 & 28 & 19 & 19 & 8 & 0 \\
\hline 6 & Word Coinage & 11 & 22 & 17 & 17 & 13 & 0 \\
\hline 7 & Literal Translation & 15 & 30 & 12 & 12 & 14 & 0 \\
\hline 8 & Code-Switching & 4 & 8 & 19 & 19 & 18 & 0 \\
\hline 9 & $\begin{array}{l}\text { Use of Nonlinguistic } \\
\text { Means }\end{array}$ & 20 & 40 & 10 & 10 & 11 & 0 \\
\hline 10 & Appeal for Help & 18 & 36 & 18 & 18 & 5 & 0 \\
\hline 11 & $\begin{array}{l}\text { Stalling or Time- } \\
\text { Gaining Strategies }\end{array}$ & 17 & 34 & 14 & 14 & 10 & 0 \\
\hline 12 & Foreignizing & 23 & 46 & 14 & 14 & 4 & 0 \\
\hline 13 & $\begin{array}{l}\text { Use of } \\
\text { Fillers/Hesitation } \\
\text { Devices }\end{array}$ & 31 & 62 & 8 & 8 & 2 & 0 \\
\hline 14 & Total & 440 & & 194 & & 0 \\
\hline
\end{tabular}

After giving the questionnaire, the researcher observed the class and got some field note of their strategies to communicate through their practice with their partner. The researcher observed the class twice. And got result as follow:

Table 2.

Data of the Communication Strategies Were Used in the Class During the First Observation

\begin{tabular}{|c|l|l|c|}
\hline No & \multicolumn{1}{|c|}{ Communication Strategies } & Tally & Frequency \\
\hline 1 & Message Abandonment & III & 4 \\
\hline 2 & Topic Avoidance & I & 1 \\
\hline 3 & Circumlocution & II & 2 \\
\hline 4 & Approximation & I & 1 \\
\hline 5 & Use of All-Purpose Words & & - \\
\hline 6 & Word Coinage & & - \\
\hline 7 & Literal Translation & I & 2 \\
\hline 8 & Code-Switching & II & 1 \\
\hline 9 & Use of Nonlinguistic Means & I & 3 \\
\hline 10 & Appeal for Help & III & 5 \\
\hline 11 & Stalling or Time-Gaining Strategies & IIII & 2 \\
\hline
\end{tabular}




\begin{tabular}{|c|l|l|c|}
\hline 12 & Foreignizing & I & 1 \\
\hline 13 & Use of Fillers/Hesitation Devices & & - \\
\hline 14 & Total & 21 & 21 \\
\hline
\end{tabular}

In the first observation the researcher got the communication strategies that was used by the students only nine communication strategies was used. The most used by the students was stalling or time-gaining strategy. After getting the data from the first observation, the researcher continued his research to the second observation in the same class in the other day. The result are : there were twenty one communication strategies were used, four message abandonment, one topic avoidance, two circumlocution, one of approximation, one literal translation, two code switching, one use of non linguistic means, three of appeal for help, five for stalling or time gaining strategies, and one foreignition. The example of the communication strategies above are:

1. Message abandonment:

Student X1: "Where do you come from?"

Student X2: "Banyuwangi, do you ever go there? Banyuwangi is the town..." (student X2
didn't continue)

2. Topic avoidance:

Student X1: "Do you have any brother or sister?"

Student X2: "Yes I have."
Student X1: "What are they?" (the student X2 didn't answer the question but he shifted the topic by asking another question to student X1)

Student X2: "Why do you choose to study in this university?"

3. Circumlocution:

Student X1: "Where is it exactly?"

Student X2: "It is near the thing that circle in the middle of street" (the student

$\mathrm{X} 2$ meant roundabout)

4. Approximation:

Student X1: I come to the campus by walk.

(The students X1 said by walk, his meant on foot)

5. Literal translation:

Student X1: "Where you bear?"(the student X1 conducted to ask "where were you born" in Indonesia it means "kapan kamu lahir")

6. Code switching strategy: 
Student X1: "Banyuwangi is city

yang indah"

("indah "the student X1 means

"wonderful" )

7. Use of non linguistics mean:

A student express his face like angry, but he didn't know the English word of Angry, so he expressed his face like angry.

8. Appeal for help:

Student X1 (asked one of his friends "'Hanya lewat what is in English?"
9. Stalling or time gaining strategy :

Student X1: "I was born amm..on

July $12^{\text {nd }}$, emm.. 1990"

10. Foreignizing:

Student X1: hey...don't be "curang"

(the subject used Indonesian word curang with English pronunciation)

After the data were tabulated, the researcher counted then got the result as:

Table 4.

The Frequent of Communication Strategies were Used in the Speaking Class.

\begin{tabular}{|l|l|c|c|}
\hline No & Communication Strategies & Frequency & Percentage (\%) \\
\hline 1 & Message Abandonment & 4 & 19.04 \\
\hline 2 & Topic Avoidance & 1 & 4.8 \\
\hline 3 & Circumlocution & 2 & 9.52 \\
\hline 4 & Approximation & 1 & 4.8 \\
\hline 5 & Use of All-Purpose Words & - & - \\
\hline 6 & Word Coinage & 1 & 4.8 \\
\hline 7 & Literal Translation & 2 & 9.52 \\
\hline 8 & Code-Switching & 1 & 4.8 \\
\hline 9 & Use of Nonlinguistic Means & 3 & 14.3 \\
\hline 10 & Appeal for Help Time-Gaining & 5 & 71.4 \\
\hline 11 & $\begin{array}{l}\text { Stalling or } \\
\text { Strategies }\end{array}$ & 1 & 4.8 \\
\hline 12 & Foreignizing & - & - \\
\hline 13 & $\begin{array}{l}\text { Use of Fillers/Hesitation } \\
\text { Devices }\end{array}$ & 21 & \\
\hline & Total & & \\
\hline
\end{tabular}

There were $19.04 \%$ message abandonment, 4. $8 \%$ topic avoidance, 9. 52\% circumlocution, $4.8 \%$ of approximation, 4. $8 \%$ literal translation, $9.52 \%$ code switching,
4. $8 \%$ use of non-linguistic means, $14.3 \%$ of appeal for help, $71.4 \%$ for stalling or time gaining strategies, and $4.8 \%$ foreignition. The most frequent communication strategies used 
by the students were staling or time-gaining strategy.

\section{Discussion}

The results of the research is closely in line to the list of communication strategies propossed by Brown (2000: 128) who stated that there are ten communication strategies that were used by the students in their speaking class. Those were message abandonment, topic avoidance, circumlocution, approximation, literal translation, code switching, use of non linguistic means, of appeal for help, for stalling or time gaining strategies, and foreignition. They used avoidance strategies when they find difficulties to communicate in certain context or topic to discuss. And sometimes they just kept silent and sometimes they opened new topic. It is the same as Dorney's (1993) statement who claims that avoidance is when speaking or writing a second/foreign language, a speaker will often try to avoid a difficult word or structure, and will use a simpler word or structure instead. Moreover compensatory strategy enables learners to use the new language for either comprehension or production despite limitations in knowledge as stated by Byalistok (1990) who states that the strategy that the learners have limitation in L2 still applying the strategy to product some words, phrases, or sentences. They were used the communication strategies above because they still have much difficulties in their learning foreign language. It is also supports the statement argued by Dorney (1993) who states that a communication Strategy is defined as a systematic technique employed by a speaker to express his or her meaning when faced with some difficulty.

\section{Conclusion}

From the results of the data analysis and the discussion above it can be concluded that the students in learning English they used all of the communication strategies to make their communication run well. However, only certain communication strategy often used by the students through their speaking class. Those were message abandonment, topic avoidance, circumlocution, approximation, literal translation, code switching, use of non linguistics means, appeal for help, stalling or time gaining strategy, and foreignizing. And the most frequent used is stalling or time gaining strategy. It was done by the students to recall their memory of the L2 that they understood to produce some words, sentence or phrases. By knowing the communication strategies are used by the students, it can be an indication that the students have trouble or difficulties in learning L2 (English). So it is recommended that the teacher must pay attention to their difficulties intensively, especially in helping them recalling the words, phrases or utterances around the topic as the 
most frequent communication strategies is stalling or time gaining strategy.

\section{Acknowledgements}

In conducting this reserach, it is known that without support from all components, this research cannot be finished well, so his gratitude is purposed to:

1. Dr. H. Samari, S.E., M.M, the Rector of Nusantara PGRI Kediri University.

2. Dr. Suryanto, M.Si, the Head of Research and Social Service Nusantara PGRI Kediri University.

3. Dra. Hj. Sri Panca Setyawati, M.Pd., the Dean of Teacher Training and Education Faculty.

4. Suhartono, M.Pd, the Head of English Department.

\section{References}

Brown, G and George,Yule. 1983. Teaching the Spoken Language. Cambridge: Cambridge University Press.

Bialystok, E.. 1990. Communication Strategies: A Psychological Analysis of Second Language Use. London: Blackwell.

Brown, H. Douglas. 2000. Principle of Language Learning And Teaching, Fourth Edition. New York: Logman.

Dornyei, Z. 1995. On the Teachability of Communication Strategies. TESOL QUARTERLY, 29, 55-58.

Ellis, Rod. 1997. Second Language Acquisition. Oxford: Oxford University Press.

Wajnryb, R. 1987. “When Silent Isn't Golden. Teaching Learners to Use Conversational Fillers". TESL Reporter, 20 (3), 47-52. 